\title{
Mitochondrial Adaptations of Obese Adult Rat Visceral Adipocytes which Differ in Nutritional Status during Childhood
}

\author{
Lailan S. Nasution, ${ }^{1,2 \star}$ Ahmad Aulia, ${ }^{3}$ Sri W.A. Jusman, $, 4,5$ Mohamad Sadikin ${ }^{4,5}$ \\ ${ }^{1}$ Department of Nutrition, Faculty of Medicine Universitas Muhammadiyah Jakarta, Jakarta \\ ${ }^{2}$ Doctoral Program in Biomedical Sciences, ${ }^{3}$ Department of Histology, \\ ${ }^{4}$ Department of Biochemistry and Molecular Biology, ${ }^{5}$ Center of Hypoxia and Oxidative \\ Stress Studies, Faculty of Medicine Universitas Indonesia, Jakarta \\ ${ }^{*}$ Corresponding author: lailansafinanasution@umj.ac.id \\ Received 4 July 2021; Accepted 13 January 2022 \\ https://doi.org/10.23886/ejki.9.48.197
}

\begin{abstract}
Mitochondria are highly dynamic organelles that can adapt to different environmental stimuli. This study aims to analyze differences in the function and biogenesis of mitochondria and anaerobic glycolysis activity between obese adult rats that were undernourished in childhood (LCD28) and those which were normal (SD28) or already fat (HFD28). Sprague-dawley rats were assigned groups and given diet treatments from December 2017 until August 2018 in the Laboratory Animal Management Unit, Faculty of Veterinary Medicine, Bogor Agricultural Institute. To observe mitochondrial function and biogenesis, MnSOD activity and PGC1a levels were analyzed using ELISA. To investigate the existence of anaerobic glycolysis, LDH activity was analyzed using a spectrophotometry method. The results showed that MnSOD activity and PGC1a levels of LCD28 increased compared to the other groups, signifying higher mitochondrial function and biogenesis. Meanwhile, no significant difference in $L D H$ activity was found, signifying similar levels of anaerobic glycolysis.
\end{abstract}

Keywords: MnSOD, PGC1a, lactate dehydrogenase, hypoxia, cell metabolism.

\section{Adaptasi Mitokondria di Sel Adiposit Viseral Tikus yang Berbeda Status Gizi selama Pertumbuhan}

\begin{abstract}
Abstrak
Mitokondria adalah organel dinamis dan dapat beradaptasi terhadap stimulus lingkungan. Penelitian ini bertujuan untuk menganalisis perbedaan fungsi mitokondria, biogenesis mitokondria, serta glikolisis anaerobik antara kelompok tikus dewasa obesitas yang mengalami kekurangan nutrisi saat masa anak-anak (LCD28) dengan kelompok tikus yang mendapatkan nutrisi cukup saat masa anak-anak (SD28) dan kelompok tikus yang mendapat kelebihan nutrisi saat masa anak-anak (HFD28). Tikus sprague-dawley dikelompokkan dan diberikan perlakuan eksperimental sejak Desember 2017 hingga Agustus 2018 di Unit Pemeliharaan Hewan Laboratorium, Fakultas Kedokteran Hewan, Institut Pertanian Bogor. Untuk mengukurfungsi dan biogenesis mitokondria, dinilai aktivitas MnSOD dan PGC1a dengan ELISA. Untuk mengukur glikolisis anaerobik, aktivitas LDH dianalisis secara spektrofotometri. Hasil eksperimen menunjukkan aktivitas MnSOD dan kadar PGC1a dari kelompok LCD28 meningkat dibandingkan kelompok lain, menunjukkan meningkatnya fungsi dan biogenesis mitokondria. Tidak ada perbedaan signifikan pada aktivitas LDH antar kelompok, menunjukkan tidak ada perbedaan signifikan dalam tingkat glikolisis anaerobik antara kelompok tikus.
\end{abstract}

Kata kunci: MnSOD, PGC1a, laktat dehidrogenase, hipoksia, metabolisme sel. 


\section{Introduction}

Obesity is linked to numerous degenerative diseases and is one of the leading causes of death worldwide. Its prevalence is continuously rising worldwide, including in Indonesia. ${ }^{1,2}$ An interesting observation is that obese adults in Indonesia could come from different childhood nutritional levels. Some might have already been obese since childhood, some might have been normal, and others yet might have been undernourished while young. The biological difference between these groups of people is not yet properly understood.

Our previous study found that visceral adipocytes from adult rats undernourished while young developed enlarged fat cells (hypertrophy). The cells were in a hypoxic condition, as proven by the significant increase of HIF-1 $\alpha$ and HIF-2 $\alpha$ protein levels. These phenomena were not found in the fat cells of rats that were normal or even overnourished in childhood. ${ }^{3}$ Therefore, further studyis needed whether there was a difference in the energy metabolism of these fat cells. It is assumed that the hypoxic conditions of these previously undernourished rats induced mitochondrial dysfunction, lowering the function and making them switch to anaerobic glycolysis to improve the efficiency of oxygen utilization for ATP production.

Mitochondria are evolutionary ancient subcellular organelles responsible for ATP generation through oxidative phosphorylation in eukaryotic cells and highly dynamic organelles that constantly undergo fusion and fission to regulate homeostasis and cell survival. It can initiate adaptive responses to different environmental stimuli, such as modifications in energy demands by altering the number of mitochondria, changing the morphology, or remodeling the organization and distribution of mitochondria within the cell. ${ }^{4}$ The morphology of mitochondria is related to the metabolic state and bioenergetics of the cell. ${ }^{5}$ The oxidative capacity could be determined by the phenotype and number of mitochondria. In obese fat cells in a hypertrophic and hypoxic condition, the mitochondria would go into stress and fail to generate and sustain adequate ATP levels. The number and biogenesis of mitochondria would decrease. ${ }^{6}$

Manganese superoxide dismutase (MnSOD, SOD2) is an integral mitochondrial protein found only in mitochondria, thus it is a useful parameter for detecting the existence and function of mitochondria. ${ }^{7}$

Peroxisome proliferator-activated receptorgamma coactivator $1 \alpha(P G C 1 \alpha)$ is an accessory protein involved in mitochondrial biogenesis regulation. The expression of PGC1 $1 \alpha$ is reduced in adipose tissue of morbidly obese subjects. ${ }^{8}$

Hypoxia-inducible factors (HIFs) are proteins that mediate cellular adaptations to hypoxia. The heterodimeric HIF transcription factors consist of HIFa and HIF $\beta$ subunits. The HIFa is comprised of HIF1 $\alpha$, HIF2 $\alpha$ and HIF3 $\alpha$. HIF transcriptional target genes stimulate cell survival, metabolism, and angiogenesis in adaptation to low oxygen. ${ }^{9}$

Anaerobic glycolysis is one of the metabolic adaptations of cells made possible by the activation of HIFs. ${ }^{10}$ Anaerobic glycolysis allows the creation of energy without oxygen, therefore it is crucial in a hypoxic condition. However, it produces only 2 moles of ATP per mole of glucose compared to 32 moles of ATP per mole of glucose in aerobic glycolysis. ${ }^{11,12}$ HIF-1 $\alpha$ has a critical role in activating the transcription of lactate dehydrogenase (LDH) and the glycolytic switch into anaerobic metabolism. ${ }^{13}$

In this study, we assessed the function and biogenesis of mitochondria and levels of anaerobic glycolysis of obese adult rat visceral adipocytes with a different nutritional status during their childhood.

\section{Methods}

This was an experimental study using spraguecawley (SD) rats as animal models. SD rats were chosen because they mimic the pathophysiology of human obesity well. ${ }^{14}$ The rats were obtained from and kept in the Laboratory Animal Management Unit, Faculty of Veterinary Medicine, Bogor Agricultural Institute. The rats were given the experimental treatment from December 2017 until August 2018. The same rats were used as the one used in our previous study, which analyzed the difference in autophagic responses of the adipocytes of obese adult rats which received different nutritional treatments while young. ${ }^{3}$ The Ethics Committee approved all procedures in this study of the Faculty of Veterinary Medicine, Bogor Agricultural Institute (number 073/KEH/SKE/X/2017).

\section{Animal Protocol}

This paper is part of a large study investigating adipocyte responses between obese rat groups given different nutritional treatments while young. We used 35 male rats aged 4 week-old, weighing 65-110 g, after two-week acclimatization, were randomly divided into 8 week and 28 week treatment groups. The 8-week groups consist of groups given a low-calorie diet (LCD8), a high-fat diet (HFD8), and a standard chow diet (SD8) as control. The 
28- week groups consist of groups given LCD for 8 weeks followed by HFD for 20 weeks (LCD28), SD for 8 weeks + HFD for 20 weeks (SD28), HFD for 28 weeks (HFD28), and SD for 28 weeks as control. Only the 28 -week groups, totaling 20 rats, were considered. The body weight of each rat was monitored weekly. The animals were individually housed in stainless steel wire cages in an environmentally controlled clean air room with a 12hour light-dark cycle. At the end of the experiment, the rats fasted for 12 hours and were terminated by intramuscular ketamine-xylazine injection. The visceral adipose tissues were collected at the end of week 28 , stored in a freezer below minus $80^{\circ} \mathrm{C}$ (SANYO MDF-U53V, SANYO Electric Biomedical Co., Ltd., Osaka) until analyzed.

\section{Diets}

Three kinds of diet were used: standard, lowcaloric and high-fat diet. The standard diet composition was made according to the Indonesia National Agency for Drug and Food Control, containing $3100 \mathrm{kcal} / \mathrm{kg}$. The low-caloric diet contained $2100 \mathrm{kcal} / \mathrm{kg}$, a $30 \%$ reduction from the standard diet and the high-fat diet contained 4200 $\mathrm{kcal} / \mathrm{kg}$. All types of diet were given as pellets for ad libitum feeding. ${ }^{3}$

\section{ELISA Analysis}

The levels of PGC1 $\alpha$ protein and the activity of MnSOD were determined by ELISA using commercially available kits (Rat PGC1a KitCat No. MBS098993 and Rat MnSOD Kit Cat No. MBS2881838 from MyBioSource.com). All procedures were conducted according to the manufacturer's protocol. The result was divided by the total protein count of the visceral adipose tissue using the Warburg-Christian method at $\lambda 280 \mathrm{~nm} .{ }^{15}$

\section{Analysis of Lactate Dehydrogenase Activity}

The LDH activity in the visceral adipocytes was determined quantitively through Thermo Scientific Multiskan GO spectrophotometer (Thermo Fisher Scientific, Wilmington, DE) using QuantiChrom ${ }^{\mathrm{TM}}$ LDH Kit (D2DH-100) from BioAssay. All procedures were conducted according to the manufacturer's protocol. The result was divided by the total protein count of the visceral adipose tissue using the Warburg-Christian method at $\lambda 280 \mathrm{~nm} .{ }^{15}$

\section{Statistical Analysis}

Results are presented as mean \pm standard error of the mean (SEM). If the data has a normal distribution, one-way ANOVA was used to compare the differences between multiple groups, followed by an LSD post-hoc test. Otherwise, Kruskal-Wallis analysis was used to compare the differences between multiple groups, followed by MannWhitney post-hoc test. Statistical analyses were performed using SPSS ver. 20 (IBM Corporation, Armonk, NY). The differences were considered significant when $p$ values $<0.05$. The graphs were created using GraphPad Prism Software ver. 5.

\section{Results}

\section{Effects of Diet on The Function of Visceral Adipocyte Mitochondria}

Figure 1 shows the effects of the treatment on the MnSOD activity of the rat groups. LCD28 had an average of $0.042 \mathrm{U} / \mathrm{mg}$ protein of MnSOD, significantly higher than HFD28 $(p=0.038)$ and SD28 $(p=0.015)$.

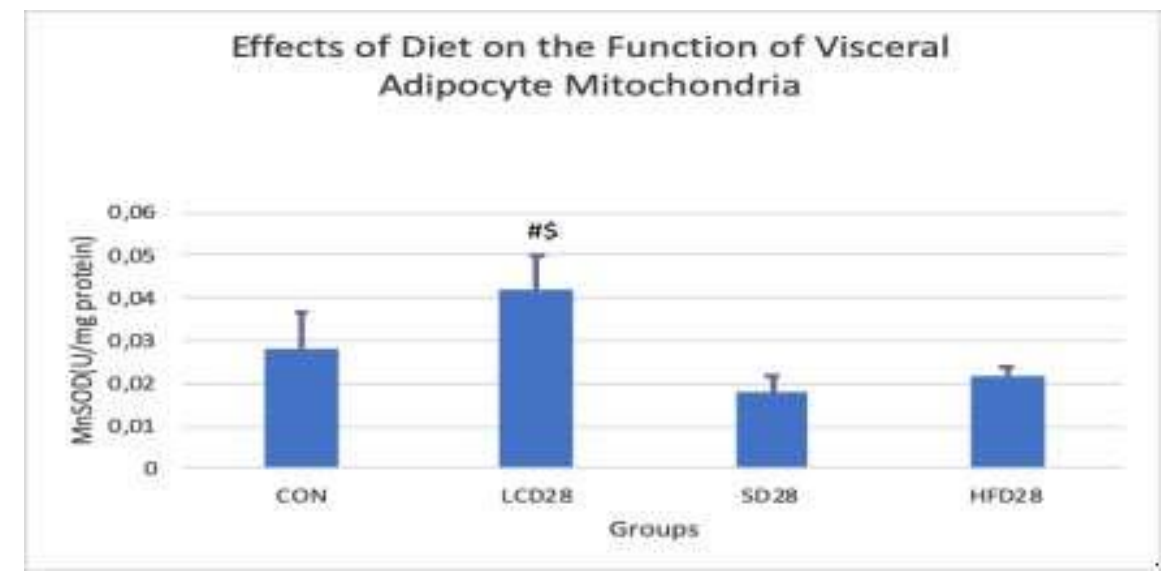

Figure 1. Effects of Diet on MnSOD Activity

Values are presented as mean \pm SEM ( $n=5$ for each group). $\$ p<0.05$ vs. SD28, \# $p<0.05$ vs. HFD28. CON: control, LCD28: low-caloric diet (8 weeks) followed by HFD (20 weeks), SD28: standard chow diet (8 weeks) followed by HFD (20 weeks), HFD28: HFD (28 weeks). ANOVA, post hoc LSD 


\section{Effects of Diet on The Biogenesis of Mitochondria}

The level of PGC1a of the LCD28 adipocytes increased significantly compared to HFD28 ( $p \leq 0.001)$, SD28 ( $\leq \leq 0.001)$ and control $(p \leq 0.001)$, as shown in Figure 2.

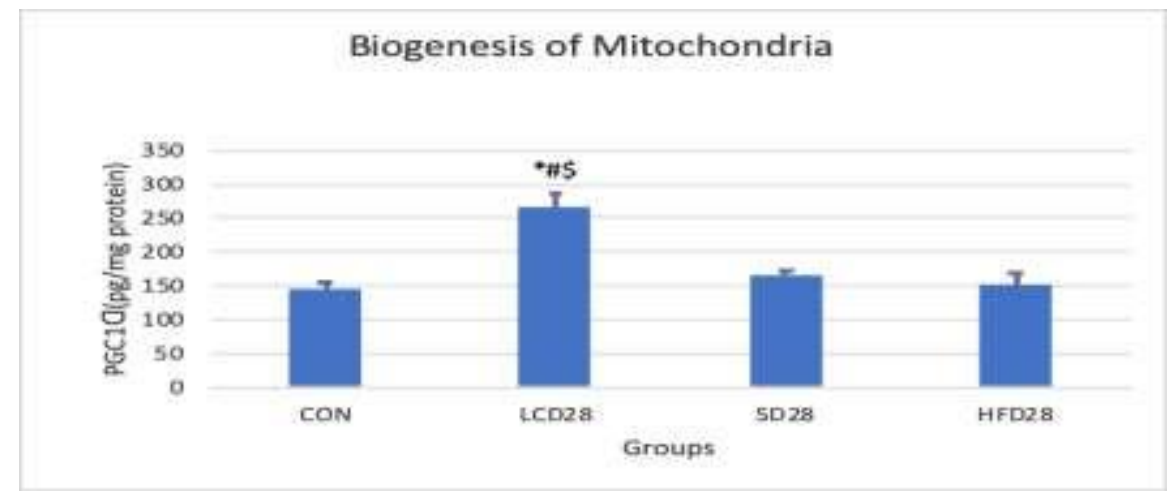

Figure 2. Effects of Diet on The Level of PGC1a

Values are presented as mean \pm SEM ( $n=5$ for each group). ${ }^{*} p<0.05$ vs. CON, $\$ p<0.05$ vs. SD28, \# $p<0.05$ vs. HFD28. CON: control, LCD28: low-caloric diet (8 weeks) followed by HFD (20 weeks), SD28: standard chow diet (8 weeks) followed by HFD (20 weeks), HFD28: HFD (28 weeks). ANOVA, post hoc LSD

\section{Effects of Diet on Lactate Dehydrogenase Activity}

There was no significant difference in LDH activity between all the experimental groups and control, as shown in Figure 3.

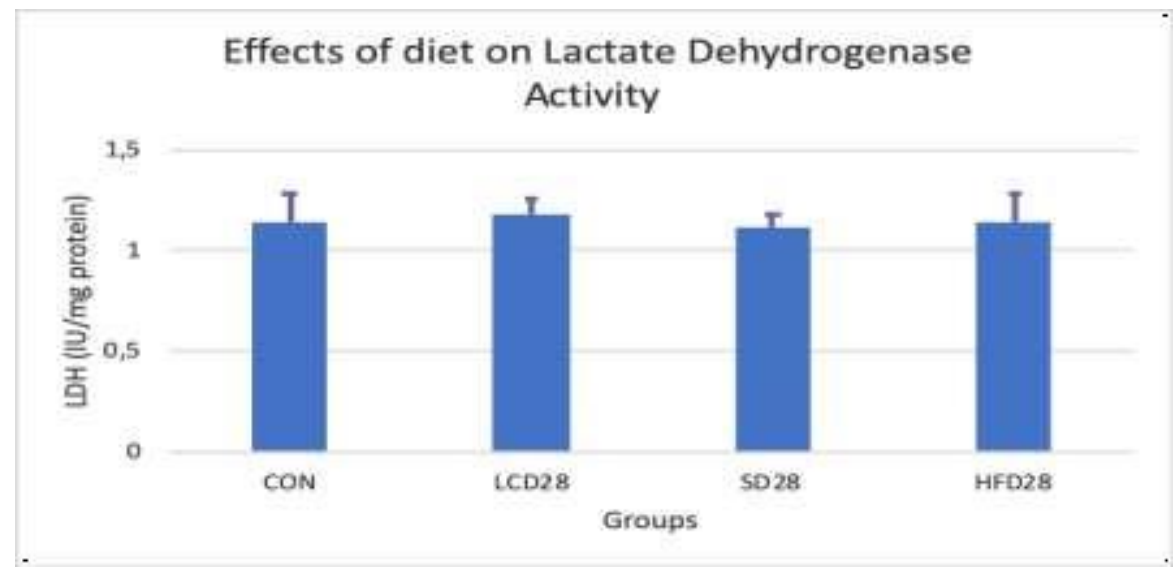

Figure 3. Effects of Diet on The LDH Activity

Values are presented as mean \pm SEM ( $n=5$ for each group). CON: control, LCD28: low-caloric diet (8 weeks) followed by HFD (20 weeks), SD28: standard chow diet ( 8 weeks) followed by HFD (20 weeks), HFD28: HFD (28 weeks). ANOVA

\section{Discussion}

The results of this study show that the PGC1a protein level and the MnSOD activity of the LCD28 group were significantly higher than the other groups, this show that the function and biogenesis of mitochondria increased since MnSOD is an enzyme found specifically in mitochondria. ${ }^{7}$ This finding is contradictory to our hypothesis. We assumed that the hypertrophic fat cells derivedfrom the rats previously undernourished in childhood would go into hypoxic condition, which should have reduced mitochondrial function and biogenesis instead.

At a glance, this situation seems contradictory. However, studies have demonstrated that in hypoxia, HIF-1 $\alpha$ and HIF-2 $\alpha$ are activated, which can play a critical role in adapting to hypoxic conditions. The activation of HIF- $1 \alpha$ and HIF-2 $\alpha$ could upregulate the proangiogenic factors, such as VEGF and the erythropoiesis genes. ${ }^{13,16} \mathrm{We}$ assume that since the LCD28 rats underwent hypoxia, HIF-1 $\alpha$ and HIF- 
$2 \alpha$ activated the proangiogenic and erythropoiesis genes, which built new vascularization and promoted oxygenation to cells. However, the VEGF was not analyzed, which could be explored in future studies.

Prior studies that induced obesity in ratswith a high-fat diet found that the rats underwent mitochondrial dysfunction, as evidenced by lowered oxidative phosphorylation and beta-oxidation in their adipocyte tissues. Anaerobic metabolism was used to lower oxygen use. PGC1a was also downregulated, lowering mitochondrial biogenesis. ${ }^{8}$ This is in stark contrast to the findings of this study, where mitochondrial function increased in the LCD28 group. It could be caused by this study's relatively short period of adulthood high-fat diet feeding. If this diet is continued longer, this condition of oxidative stress might cause mitochondrial damage, causing the function and biogenesis of mitochondria to take a turn for the worse. On the other hand, there was no significant difference in the function and biogenesis of mitochondria between SD28, HFD28 and the control group. It might be that the adequate nutrition these groups received during childhood promoted good vascularization during their development, causing good oxygenation in their cells and allowing the mitochondria to perform well.

Mitochondria are highly dynamic organelles that constantly undergo fusion and fission ${ }^{5,17}$ making it difficult to determine the exact number of mitochondria per cell. Although numerous research had been conducted to calculate cellular mitochondria, there is no gold standard to measure it yet. Researchers have determined it in various ways, biochemically or using certain machines and software. Recently, mitochondrial image analysis using automated machine learning and analysis software is also available. This quantitative method is claimed be able to analyze the morphology, texture, motion, and morphogenesis of mitochondria. ${ }^{17}$ Other researchers analyzed the activity of mitochondrial enzymes or the changes in the expression of genes for encoding those enzymes. ${ }^{18}$ In this study, MnSOD (SOD2) was used as a parameter because this protein is specific, found only in mitochondria. ${ }^{17}$ With this method, we found a significant difference in MnSOD activity between the rat groups, which illustrates a difference in mitochondrial function between the groups.

This study showed no significant difference in the LDH activity between groups compared to control, although the HIF-1 $\alpha$ and HIF- $2 \alpha$ protein levels of the LCD28 group increased significantly. This signifies a similar level of anaerobic glycolysis between LCD28 and the other groups, which is unexpected since LCD28 underwent hypoxia. This contradicts our hypothesis, which states that obese rats undernourished at childhood would undergo more anaerobic glycolysis.

Since we found earlier that the biogenesis in mitochondria increased in LCD28, we can take this as proof that aerobic glycolysis still happened, therefore, sufficient ATP is produced within the cells, reducing the need for anaerobic glycolysis. On the other hand, HFD28 and SD28 adipocytes did not experience hypoxia, so they could normally run the aerobic metabolism normally.

The LDH enzyme is comprised of 4 subunits. Each combination of subunits forms different variations or isoenzymes found in different amounts in tissues throughout the body. Each isoenzyme consists of 4 subunits, with the most common subunits being heart $(H)$ and muscle $(M)$. From these 2 subunits, 5 isoenzymes can be formed, namely $\mathrm{HHHH}, \mathrm{HHHM}, \mathrm{HHMM}$, HMMM, MMMM. Isoenzymes with more $\mathrm{H}$ subunits are found in more aerobic tissues such as the heart, whereas isoenzymes with more $M$ subunits are often found in the muscles and the liver. ${ }^{19}$ However, we did not measure the LDH isoenzymes, so we did not find information regarding the isoenzymes found in each group compared to the control.

\section{Conclusion}

This study has proven biological differences in the adipocyte tissues of obese rats that were previously undernourished, normal and overnourished in their childhood. The function and biogenesis of mitochondria in the visceral adipocytes of obese adult rats that were previously undernourished in childhood were higher than other groups. The anaerobic glycolysis levels remained the same between all groups.

\section{Acknowledgements}

This research was supported by Doctoral Final Assignment Grants from the Faculty of Medicine Universitas Indonesia and Faculty of Medicine Universitas Muhammadiyah Jakarta.

\section{References}

1. Apovian CM, Riffenburg KM. Perspectives on the global obesity epidemic. Curr Opin Endocrinol Diabetes Obes. 2017;24:307-9. 
2. Laporan Nasional Riskesdas 2018. Jakarta: Kementerian Kesehatan; 2018. Indonesian.

3. Nasution LS, Jusuf AA, Jusman SW, Sadikin M. Hypoxia and autophagic response of obese adult rat adipocytes which differ in nutritional state during childhood. J Clin Biochem Nutr. 2019:19-74. https://doi.org/10.3164/jcbn.19-74.

4. Seungyoon BY, Pekkurnaz G. Mechanisms orchestrating mitochondrial dynamics for energy homeostasis. J Mol Biol. 2018;430:3922-41. https://doi.org/10.1016/j.jmb. 2018.07.027

5. Cedikova M, Kripnerová M, Dvorakova J, Pitule P, Grundmanova M, Babuska V, et al. Mitochondria in white, brown, and beige adipocytes. Stem Cells Int. 2016;2016.https://doi. org/10.1155/ 2016/6067349

6. Heinonen S, Buzkova J, Muniandy M, Kaksonen R, Ollikainen M, Ismail K, et al. Impaired mitochondrial biogenesis in adipose tissue in acquired obesity. Diabetes.2015;64:3135-45.https:// doi.org/10.2337/ db14-1937

7. Silig Y, Tas A, Pinarbasi $\mathrm{H}$. Manganese-superoxide dismutase (MnSOD) polymorphisms/ Manganezsüperoksit dismutaz (MnSOD) polimorfizmi. TJB. 2015;40:163-8.https://doi. org/10.5505/tjb.2015. 15689

8. Kusminski CM, Scherer PE. Mitochondrial dysfunction in white adipose tissue. Trends Endocrinol Metab. 2012;23:435-43. https://doi.org/10.1016/ j.tem.2012.06.004

9. Chee NT, Lohse I, Brothers SP. mRNA-to-protein translation in hypoxia. Mol Cancer. 2019;18:1-13. https://doi.org/10.1186/s12943-019-0968-4

10. Bao X, Zhang J, Huang G, Yan J, Xu C, Dou Z, et al. The crosstalk between HIFs and mitochondria dysfunctions in cancer development. Cell DeathDis. 2021;12:1-13. https://doi.org/ 10.1038/s41419- 02103505-1
11. Stipanuk MH, Caudill MA. Biochemical, physiological, and molecular aspects of human nutrition-E-book Philadelphia: Elsevier health sciences; 2018 p.162-3.

12. Melkonian EA, Schury MP. Biochemistry, anaerobic glycolysis. Treasure Island: StatPearls; 2019.

13. Shay JE, Simon MC, editors. Hypoxia-inducible factors: crosstalk between inflammation and metabolism. Semin Cell Dev Biol. 2012. https://doi.org/10.1016/j.semcdb. 2012.04.004

14. Marques $C$, Meireles M, Norberto S, Leite J, Freitas $J$, Pestana D, et al. High-fat diet-induced obesity rat model: a comparison between Wistar and spraguedawley rat. Adipocyte. 2016;5:11-21. https://doi.org/10.1080/21623945.2015.1061723

15. Simonian MH, Smith JA. Spectrophotometric and colorimetric determination of protein concentration. Curr Protoc Mol Biol. 2006;76:10.1.1-.1A.9. https://doi.org/ 10.1002/ 0471142727.mb1001as76

16. Jun JC, Devera R, Unnikrishnan D, Shin MK, Bevans-Fonti S, Yao Q, et al. Adipose HIF-1a causes obesity by suppressing brown adipose tissue thermogenesis. J Mol Med. 2017;95:287-97. https://doi.org/10.1007/s00109-016-1480-6

17. Zahedi A, On V, Phandthong R, Chaili A, Remark $G$, Bhanu B, et al. Deep analysis of mitochondria and cell health using machine learning. Sci Rep. 2018;8:1-15. https://doi.org/10.1038/ s41598-01834455-y

18. Urbanova $M$, Mraz $M$, Durovcová $V$, Trachta $P$, Kloučková J, Kavalkova $P$, et al. The effect of very- lowcalorie diet on mitochondrial dysfunction in subcutaneous adipose tissue and peripheral monocytes of obese subjects with type 2 diabetes mellitus. Physiol Res. 2017;66:811-22. https://doi.org/10.33549/physiolres.933469

19. Klein R, Nagy O, Tóthová C, Chovanová F. Clinical and diagnostic significance of lactate dehydrogenase and its isoenzymes in animals. Vet Med Int. 2020;2020. https://doi. org/10.1155/ 2020/5346483 